\title{
Misztikum és vallásosság: zarándoklat a Señor de Qoyllur R'ity-hez. Szinkretizmus egy indián ünnepen (Schiller Katalin)
}

\section{Bevezetés}

A spanyol hódítás során az amerikai kontinensen élô indián népeket sorra a keresztény hitre térítették. Missziókat állítottak fel, templomokat építettek, és megkeresztelték az ôslakosokat. Így mára a LatinAmerika országaiban élôk kereszténynek vallják magukat. Tartják az ünnepeket, hagyományokat, és hivatalosan teljesen átvették a keresztény rendet és értékeket.

A térítés az ôsi tradíciók elpusztulását jelentette, azonban az ôsi hitvilág és az ôsi rítusok bizonyos elemei fennmaradtak és új köntösben élnek tovább. Marót Károly szerint nincs történeti folytonosság a rítusok megismétlései között. Minden alkalommal új lelki, társadalmi és kulturális helyzetek hozzák létre az adott rítust.

Jelen írás a Señor de Qoyllur R'ity zarándoklat keresztény és ôsi elemeinek keveredését mutatja be, valamint azt, hogy napjainkban milyen külsố és belsố okok hozzák létre ezt az ünnepet, és hogy hogyan kapcsolódik mégis a múlthoz.

Az ünnep és a zarándoklat összetettsége és jelen írás terjedelme miatt itt csak a lényeg bemutatására szorítkozom, és csak a fontosabb részleteket emelem ki. 


\section{A terepmunka}

2001 júniusában vettem részt a zarándoklaton társaimmal: egy fotográfussal (Kurdi Zoltán) és egy néptáncossal (Koncz László) együtt léptünk kapcsolatba az ünnep egyik közösségével, a paucartambói ukukuk csoportjával.

A terepmunka során a kulturális antropológia módszereit használtam, vagyis a résztvevố-megfigyelést és a strukturált és a strukturálatlan interjúkat, valamint a hétköznapi beszélgetéseket.

\section{A helyszín}

Apu (Szent) Qoyllur R’ity zarándoklatának helyszíne Peru egyik déli tartományának, Cuzco megyének észak-keleti részén helyezkedik el, az Ausangate (6384m) havas hegycsúcsaihoz közel, nyugati irányban. A hegy és a völgy, ahol a szertartások zajlanak, valamint a környék egyéb elnevezései adatközlőink és a szakirodalom szerint is nehezen megnevezhetô, ui. nem egyértelmúen használják a különbözố neveket.

Kiindulópontunk, és egyúttal közösségünk a területtôl kb. 75 km-re északra fekvố Paucartambo (Cuzcótól észak-keletre fekszik). Nagyjából 600 fốnyi lakossága kétnyelvú, ill. spanyolul nem beszéló kecsua indiánokból és meszticekbôl áll. Földmúvelésbôl élnek, a közeli hegyoldalakon kukoricát és más növényeket termesztenek.

Az ünnepeken viszont, nemcsak ôk vesznek részt, hanem rokonaik és azok rokonai is. Így lehetséges, hogy minden ünnepen jelentôsen megnố a városka lakossága, és a közvetlen résztvevôk nagy része valójában nem is a faluban lakik. 


\section{A közösségek}

Az ünnep résztvevôi nem egyénileg teszik meg a zarándokutat, hanem jelmezes csoportokat, közösségeket alkotnak. Hogy az egyén melyik csoport tagja lesz, azt szabad választás alapján dönti el. Az újoncnak meg kell felelnie a csoport elvárásainak, és át kell esnie a beavatási szertartáson, amelyre a zarándoklat során, a Szent Gleccseren kerül sor.

A jelmezes csoportok együtt alkotják a nemzetségeket (nación), amelyek olyanok például, mint egy falu közössége. Elképzelhetô azonban, hogy más szempont szerint is alakul a nemzetség, például rokoni vagy baráti kapcsolat alapján.

A nemzetségek pedig együtt alkotják azt a csoportot, amely magát az „Andok népé”-nek tartja, függetlenül attól, hogy a csoporton belül megjelennek etnikai (kecsuák, aymarák stb.) vagy nemzeti (Ecuador, Peru, Bolívia) különbségek. A résztvevók mindenképpen az összefogásról beszélnek, és arról, hogy az „Andok népe” az a vallási közösség, amely a zarándoklatot együtt járja végig.

Jelen tanulmány fôszereplôje a paucartambói nemzetség, amely négy jelmezes csoportra oszlik az ünnep során. A városkában egyébként más ünnepen más csoportok is megjelennek, például a városka védôszentjének ünnepén (Virgen de Carmen - Karmelita Szent Szúz) 19 csoport és tánc jelenik meg. A Qoyllur R'ity ünnepén azonban csak négy csoportról beszélhetünk. Melyek ezek?

\section{A jelmezes csoportok és szimbólumaik}

A csoportok a történelem során folyamatosan, különbözó motivációk hatására alakultak ki. Feltételezésem szerint eredetileg másfajta vallási képzetekhez, rítusokhoz kapcsolódtak, és késốbb kerültek be a Qollyur R'itty ünnepkörbe. Tartalmuk általában vagy ôsi, vagy éppen modern gyökerekbốl táplálkozik, de kifejezetten nem a ke- 
resztény hagyományokból, ezért nem egyértelmú az összefüggés a jelmezes csoportok és a szent tisztelete között. Mégis a szertartássorozat egyik legfontosabb részét képezik ezek a csoportok és a szimbolikájuk.

A zarándoklaton eredetileg háromféle csoport vett részt:

1. az ukukuk csoportja

2. a Ch'unchók csoportja

3. a Qollák csoportja.

Ez azt jelenti, hogy minden nemzetség ugyanezeket a csoportokat állította ki. Késóbb azonban csatlakoztak ezekhez más jelmezes csoportok is, és mára a zarándoklat helyszínén, a Sinakara-völgyben egyéb jelmezesek is megjelennek, mint pl. Capaq Negro, Qoyacha, Majeño stb. csoportok. Vagy gyakran látni egyszerúen népviseletbe öltözött közösségeket, amelyek a saját helyi zenéjükre saját táncukat táncolják.

Minden csoportnak megvan a saját viselete, zenéje és tánca, amelyet az ünnep során többször eltáncol. A viseletet csak alkalmanként veszik fel.

A csoport belsố szerkezete hierarchikus, ennek ellenére nincsenek kiváltságok. Ez azt jelenti, hogy pl. a csoportnak ugyan van egy vezetôje (caporal), aki komoly tekintélynek örvend, és aki a csoport vezetését igen nagy tisztességnek tekint, elójogokkal azonban nem rendelkezik. Mindenki engedelmeskedik neki és tiszteli. Ó szervezi meg a csoportot, az ô feladata, hogy megteremtse a szükséges anyagi alapot, hogy a csapat el tudjon menni a Qoyllur R'ity-re, és a zarándoklat megvalósítása is az ố felelôssége. Ố ügyel a csoporton belüli fegyelemre, és a fegyelem elôsegítése érdekében használhatja ostorát, amely az ukukuk egyik legfontosabb eszköze. A zarándoklat során azonban igen ritka a fegyelmezetlenség.

A paucartambói jelmezes csoportok a következók:

1. Az ukuku a medveember. Róla egy legenda szól, amelyet adatközlônk így mesél el: „A medveember beleszeret egy gyönyörú szép (indián) lányba. El is rabolja a lányt, hogy vele éljen, de az nem 
akar vele maradni. Ezért elengedi. Késôbb azonban mégis udvarol neki, és elnyeri szerelmét. A lány a felesége lesz, és palotájába költözik. Boldogságuk azonban nem tart sokáig. A lányt elvarázsolják. Megbetegszik, és meghal. A medveember bánatában a hegyekbe menekül, és ott bujdosik hátralévố életében."

Ez a történet nem ismeretlen számunkra, hiszen mindnyájan ismerjük a Szépség és a Szörnyeteg meséjét, amely ugyanezt a témát dolgozza fel. „Nem véletlen a hasonlóság - kommentálja adatközlónk, majd hozzáteszi - , a legérdekesebb az, hogy ezen a területen egyáltalán nem élnek medvék. Mégis egy ôsinek tûnô mesében a fôszerepló a medve. Talán az európaiak hozták magukkal” - fejezi be a történetet.

Az ukuku tehát a medveembert szimbolizálja, és feltehetôen az európai tradíció hatását mutatja. Feladatát viszont ôsi hagyomány: ô a közvetítố a három világ között, amelyre az Andok népeinek világképe épül. Ezek az Ukhupacha, vagyis az ôsök, a holtak birodalma; a Kaypacha, vagyis a mi világunk, az élók világa, végül a Hanaqpacha, vagyis a mi és a holtak világán kívül esố világ.

Viselet és néhány fontosabb kellék:

- pellón: suba, lámagyapjúból és alpaka fonalból,

- maszk: fekete alpaka gyapjúból, Qoriwaqollo-nak is hívják,

- fejfedô: alpaka szôrboól,

- qolquewaraka: ostor, kemény, fonott bőrból,

- qoriwaraka: kereszt,

- pututu: valamilyen növény terméséból készült síp. Megfújáskor erốs, misztikus hangot ad. Bizonyos források szerint ezzel hívja elô az ukuku a rossz vagy a jó energiákat, attól függôen, mire van szüksége. Emellett ezzel jelzi bátorságát, merészségét, erôs kiállását és a gyôzelmet. Az Ukuku zenekar hangszerei eredetileg: 2 pito (ötlyukú síp) és 1 bombo (nagydob, pergôdob). A sípot oldalt fújják, mint a fuvolát. Ezek eredetileg nádból készültek, ma azonban természetes, hogy múanyag csövet is használnak, amit nylonzacskóval hangolnak. 
2. A Ch’unchók csoportja képviseli az ôserdei népeket, és viseletük is annak felel meg, ahogy az Andok földmúvesei elképzelik az ôserdô lakóit. Vagyis ruhájuk tarka, hímzett, fejüket nagy, színes papagájtollakkal díszített fejfedó borítja. Mindig elkísérik Señor de Qollyur R'ityt, minden ünnepre.

A Ch’unchókat kettôsség jellemzi több értelemben is: egyrészt szimbolikusan ók képviselik az ökológiai és etnikai különbségeket (hegyvidék és ôserdô, chunchók létezô ôserdei népcsoport és a kecsuák közti különbséget), másrészt az idôbeli és történelmi különbségeket (mindkét csoport az Inka Birodalom része volt, tehát jelenlétük a történelmi folytonosságot jelképezi, ugyanakkor távolságot is keltenek ezzel, hiszen az Inka Birodalomról már csak történelmi távlatokban beszélhetünk, vagyis a múltat és jelent jelképezik egyszerre).

A kettôsség ezeken kívül magában a Ch’uncho táncos csoportban is megjelenik, ugyanis két Ch'uncho csoport létezik: a Wayri Ch’unchók csoportja, és a Kapac Ch'unchók csoportja. Az elsố a szegény közösségek csoportja. A második csoportot idegeneknek nevezték, mivel Kapac kecsua nyelven azt jelenti, hogy gazdag, hatalmas, és nehéz elképzelni, hogy az Andok vidékén a földmúvesek gazdagok lennének.

Paucartambóban, már csak Kapac Ch’uncho csoport van, melyek a rájuk jellemzó tarka, gazdagon díszített viseletet hordják.

3. A szegénység ellenpontozására pedig egy másik csoport szolgál, amely a kereskedốk gazdagságát szimbolizálja, ugyanis az állattartás, üzlet, kereskedelem, csempészet stb. területérôl származik. Ők collaok-nak hívják. Ezért nevezik az óket szimbolizáló táncosokat Qolláknak. Két csoportjuk van: a kapac qollák és a waqcha qollák. Az elôbbiek náluk is a kereskedôk gazdagságát szimbolizálják a viseletük és koreográfiájuk révén. Utóbbiak pedig ez esetben is az Andok földmúveseit jelképezik. 


\section{Az ünnep bemutatása}

\section{Qoyllur R'ity mítosza}

Az ünnep a hagyomány szerint körülbelül 200 éves. Jézus 1780-ban jelent meg ezen a területen, és ez a jelenés lett maga a szent, a Hó Csillaga, azaz kecsua nyelven, Qollyur R’itty. A szót nem szokták lefordítani, mindenki, akár az ország más részeiben is a kecsua elnevezést használja.

A történet föszereplője egy Mariano Mayta nevú indián fiú, aki azt a feladatot kapta, hogy vigyen fel egy lámanyájat a Qolqepunkuhegy Sinakara nevú völgyébe. Ô ezt meg is tette, és hónapokat töltött el odafönt, ahol nagyon fázott, és mivel nem igen volt mit enni, éhezett. Már jó ideje fönt élt a hegyen, és nagyon szenvedett, mikor egyszer csak, szinte a semmiból, megjelent egy mesztic fiú, aki fönt maradt vele. Nagyon jó barátokká váltak, és ettôl kezdve együtt töltötték az idôt. A mesztic fiú ruhát és élelmet ajándékozott Marianónak.

A fiúnak volt egy ponchója, ami nagyon megtetszett Marianónak. Elkérte tốle, és lement vele Cuzcóba, a városba, hogy varrasson magának egy ugyanolyat. Amikor azonban a szabó meglátta a ruhát, elcsodálkozott, mert olyan anyagokból volt, amiból csak az érseknek készítettek ruhát. Nem tudta, mit tegyen, ezért a fiút elküldte az érsekhez. Don Moscoso, az érsek, meghallgatta a poncho történetét, és dühbe gurult. Követeket küldött a Sinakara-völgybe, hogy kézre kerítsék és kifaggassák a mesztic fiút. Amikor azonban felértek, nem láthatták meg ốt, mert olyan fény áradt belôle, ami megvakította a követeket. Elfogni pedig azért nem tudták, mert keresztre feszítve találtak rá. Ezért azt hitték, meghalt. Amikor Mariano fölért, ô is a keresztre feszített testet találta meg. Ó is azt hitte, hogy testi-lelki jó barátja halott. Ezt nem bírta elviselni, és belehalt fájdalmába. Ott a Sinakara-völgyben temették el. Úgy tartják, hogy a keresztre feszített mesztic fiú Jézus Krisztus egy jelenése volt, és ezért szentként tisztelik. 
A helyre elôször egy feszületet emeltek, majd a hatvanas években egy kápolnát építettek, ez lett a zarándokút célpontja.

\section{A zarándoklat rítusainak bemutatása}

a) Las visitas, vagyis a látogatások

A visita, vagyis látogatás a Qollyur R’ity elôestéjének programja. Azt jelenti, hogy a különbözố csoportok végiglátogatják egymást. Egyik csoport elmegy a másikhoz, harmadikhoz, majd a harmadik látogatja meg az elsốt. Mindenki tiszteletét teszi a másiknál, hogy a zarándoklat a szeretet és az összetartozás jegyében telhessen el. Ezt ekkor alapozzák meg.

\section{b) A romería}

A Qoyllur R'ity napján az összes csoport a saját házában gyülekezik, majd megindul a templomba, ahol misén vesz részt, amely az ünnepség kezdetét jelenti. Ezután elindul a temetôbe, ahol a holtak lelkét kérik segítségül, hogy megvalósíthassák a zarándokutat. Bevonulnak a temetôbe, és azoknak a sírjához mennek el, akik valaha részt vettek az adott csoporttal a zarándokúton. A sír mellett megállnak, imádkoznak, a zenekar pedig eljátssza a zenéjüket és a himnuszukat.

\section{c) Az indulás}

A Qoyllur R'ity napján a feladatok a kocsiúttal kezdôdnek: a csoport platós teherautón utazik, mivel Peruban ez a személyszállítás egyik igen népszerú jármúve. Az ukukuk az oldalfal tetején foglalnak helyet, ostorukkal a rúdhoz, és a kocsi stabil részeihez kötik magukat, nehogy leessenek, ha esetleg elaludnának. A zenészek megállás nélkül muzsikálnak, miközben az ukukuk ütemesen fújják sípjukat. Az utazás 12 órán keresztül tart 2 hivatalos állomással. 


\section{d) Mahuayanitól a Sinakaráig}

Mahuayani szerepe azért fontos, mivel itt hagyják a kamionokat, buszokat, és innen indul az igazi, gyalogos zarándoklat. Egy rövid séta után piaci forgatagban találja magát a zarándok: standok állnak egymás mellett sorban, mindenfelé sütnek, fốznek, füst és különféle furcsa szagok terjengenek a levegóben.

Több óra gyaloglás után, kanyar kanyart követ, mire a zarándok végre megpillantja a völgy bejáratát, azaz a vásári forgatagot. A forgatag elốtt árusok ételt, italt, cigarettát és csokoládét kínálnak. Az ember nehezen verekszi át magát a tömegen, de amikor sikerül, végre elétárul a Völgy.

Ez tulajdonképpen nem más, mint egy fennsík, melyet körben hegyek vesznek körül. Szemben a havas hegyoldal: a Qolquepunku, a Szent Gleccser, oldalt pedig egy hidegvízú patak rohan, mely valahonnan a hegy gyomrából jön, és a kápolna környékén már nyoma sincs. A patakban emberek fürdenek ruhástul, hajukat mossák, tisztító fürdốt vesznek. Nincs se pap, se más vallási specialista, aki e rítust irányítaná.

A paucartambói ukukuk a nagy tisztáson, a kápolnától kissé meszszebb, az illemhely mögött vernek tábort. Ez a „camping” széle még, de estére rengeteg új sátrat vernek fel, ponyvát helyeznek le, így a tábor széle kitolódik.

A paucartambói ukukuk táborverése nem azt jelenti, hogy sátrakat állítanak fel, hanem egyszerúen leteszik a holmijukat, és letelepszenek, a szieszta idejére. Most kipihenik magukat, mert az idevezetố gyalogtúra csak a kezdete volt az ünnep rítusainak.

\section{e) A Sinakara-völgy, a körmenet}

A völgyben zajlik az élet. A csoportok jönnek-mennek, akik kipihenték magukat azonnal táncra kelnek, mindenki a saját zenéjére táncol. A kápolna hangosbemondójából megállás nélkül kecsua nyelvú prédikáció hallatszik, de szinte senki sem figyel a szövegre. 
Egyszer csak megkezdôdik a körmenet. A külsô szemlélônek elôször nem túnik fel semmi, mintha semmi sem változott volna. Vásári forgatag, zene, tánc, kavalkád, füst. A változás annyi, hogy a körmenetnek pontos rendje van: megvan az útvonal, amit a csoportoknak be kell járniuk. A templom elôl indulnak el, és oda érkeznek vissza. Ott, a templom elôtti kis téren táncolnak, énekelnek és zenélnek. A körmenet alatt a sapkákat leveszik, fontos, hogy harangozáskor pontosan félóránként - fedetlenek legyenek. Miközben a paucartambói nemzetség a körmeneten vesz részt, az „öregek” csoportja külön feladatot lát el. Ök viszik fel az ukukuk keresztjét a Szent Gleccserre, egy pontos helyre, ahová már csak ók mehetnek fel.

A Sinakara-völgyben nem látni vallási specialistákat, és maga az egyház sincs jelen. A kis kápolnán és a 2-3 papon kívül, egyházi személy hivatalos minôségben nem tartózkodik a völgyben. Maga a kápolna díszítetlen, és betonépület benyomását kelti. Tetején egyszerú, közepes kereszt látható.

Az állam sincs jelen az ünnepen. Nincsenek katonák, se rendôrök, se más rendfenntartó erôk, csak az ukukuk, akik ezt a feladatot is ellátják a területen. Nekik van joguk ahhoz, hogy a „zavargókra” ostorukkal odasújtsanak.

\section{f) Az ünnepség csúcspontja: a Szent Gleccser}

Kis pihenô után éjfélkor elindul a kis csapat a Szent Gleccser felé. Pár száz métert kell felkapaszkodni a meredek hegygerincen. Fent a társaság a Gleccser szélénél megáll, és megvárja a napfelkeltét. Eközben, még napfelkelte elốtt, megindul a zarándokok áradata a Szent Gleccser felé, és mire megjelennek az elsô napsugarak, a környéken már igen nagy tömeg gyúlt össze.

Megkezdôdik a szertartás a Szent Gleccseren. Imádkozás közben megjelennek a nap elsố sugarai. Ekkor megy végbe a találkozás a Szent Gleccserrel és magával a Nappal.

Miért is olyan fontos ez a „találkozás”? - kérdezem adatközlóimet. Azt válaszolják, azért, mert a Szent Gleccser, a szent jég nem más, 
mint szent víz, az Úr szentelt vize, melyet Ô maga tett szentté. És mivel az Úr csodákra képes, így az Ô vize is csodákra képes. Isten teremtette a világot, tehát a világ Isten része, vagyis Isten a világ része. Tehát, a jég megérintése a közvetlen kapcsolat a szentséggel, vagyis Istennel. A hegy tisztelete egyben Isten tisztelete is, és a hegy vére a jéggé fagyott víz, egyben Isten vére is, így általa közvetlenül az Úrral érintkezik az ember és közvetlenül az Úr révén tisztul meg. Ezért nincs szükség itt se papra és se az egyházra, mert a kapcsolat itt közvetlenül jön létre Istennel.

A napfelkelte pedig azért fontos, mert a Nap is Isten szimbóluma, és a találkozás a Nap elsố sugaraival megerôsíti ezt a közvetlen kapcsolatot.

A téma egyik kutatója, Robert Randall (1982) szerint, a Qoyllur R'ity szertartássorozatában igen kevés olyan jelenséget találunk, mely tisztán kereszténynek lenne mondható. A rituális fürdô a patakban vagy a hóban való megtisztulás is ôsi motívumokra vezethetố vissza. Vagy akár maga a hegy tisztelete is. Szerintem itt egyszerủen a két vallás keveredésérôl van szó, az ôsi és keresztény hit elemeinek összeolvadásáról.

A hegy tisztelete az ôsi, panteista vallás egyik alapja az Andokban, azonban a Hegy ebben az esetben összekeveredik egy tipikus keresztény motívummal, a szentjelenéssel. A Nap mint az ôsi fóisten is megjelenik, de már a keresztény (teremtô) Isten szimbólumaként. A rituális fürdô pedig ugyanúgy kapcsolódik ôsi rítusokhoz, mint a keresztény szertartásokhoz. A víz mint a Hegy vére fontos szimbólum, de nem felejtkezhetünk el magáról a keresztelés rítusáról sem, amelyet szintén vízzel végeznek (ráadásul Keresztelô Szent János is a Jordánban keresztelte meg Jézust). (Máté 3.12.)

Tehát, a Hegy tisztelete egyben egy katolikus szent tisztelete is. Ugyanakkor Qollyur R'ity az emberek fejében megegyezik a Hegygyel, ezért érintkezhetnek a szenttel a hegy elemein (Szent Gleccser, szent patak stb.) keresztül. Adatközlôink többször is elmagyarázták, hogy Isten teremténye a világ, tehát, a világ darabkái Isten darabkái 
is egyben. Isten benne van minden darabkában, tehát egy darab magába foglalja Istent. A Hegy is Isten része, így a tisztelete Isten tisztelete is egyben.

Arra a kérdésre pedig, hogy miért pont ez a hegy a szentként tisztelt Hegy, azt válaszolták, hogy Isten jelölte meg ezt a csúcsot a szentjelenéssel és ezért ez az a hely, ahol közvetlenül lehet kapcsolatba lépni Istennel.

A képzetekben tehát, egyszerre van jelen az ósi tradíció és annak keresztény magyarázata is. Ugyanezt figyelhetjük meg a rítusok végzésében, hiszen a keresztény zarándoklatot ôsi hagyományokon alapuló jelmezes csoportokban végzik.

g) A gyalogút a hegyháton

A zarándoklat egy 24 órás gyalogút keretében ér véget, ahol nemcsak menetelnek, hanem újabb rítusokat végeznek el, amelyek gyökere az ôsi idôkre nyúlik vissza, és inkább a jelmezes csoportokhoz kötôdik, mint a szenthez.

\section{Irodalom}

- Achahui Tapia, F. Martínez Cernades, M. Santos Rodríguez, H. 2001: Las lágrimas de sangre ded Apu Qollyurrit'i. In: Ausangate. Año 13. No.13. Mayo-Junio. 4-11. old.

- Boglár Lajos 1995: Vallás és antropológia. Budapest: Szimbiózis

- Flores Lizana, C. 1997: Taytacha Qollyur R'ity: teología india hecha por los comuneros y mestizos quechuas. Cuzco

- Flores Ochoa, J. A. 1990: TAYTACHA QOYLLURIT'I: El Cristo de la nieve resplandeciente. In: Cuzco.Resistencia y Continuidad. No.1. Cuzco

- Gow, David D. 1974: Taytacha Qollyur Rit'i. In: Allpanchis Phuturinqa 7.

- Marót Károly 1945: Survival és revival. In: Ethnographia. 1945. 1-9. old.

- Marót Károly 1940: Rítus és ünnep. In: Ethnographia. 49. 
- Poole, Deborah 1979: Taytacha Qollyur R'iti. In National Geographic. Vol. 153. No.2. February.

- Poole, Deborah 1988: Entre el milagro y la mercancía: Qoyllur R'ity. In:

- MARGENES. Año II., No. 4. 101-120

- Randall, Robert 1982: Qoyllur R'ity an Inca fiesta of the Pleiades. In: Boletín del Instituto Francés de Estudios Andinos. Tomo XI. No. 1-2. 37-81 old.

- Santos Rodríguez, J. H. Martínez Cernades, M. 2001: El Paulucha o

- Ukuku. In: Ausangate. Año 13. No.13. Mayo-Junio. 2-3 old. 